
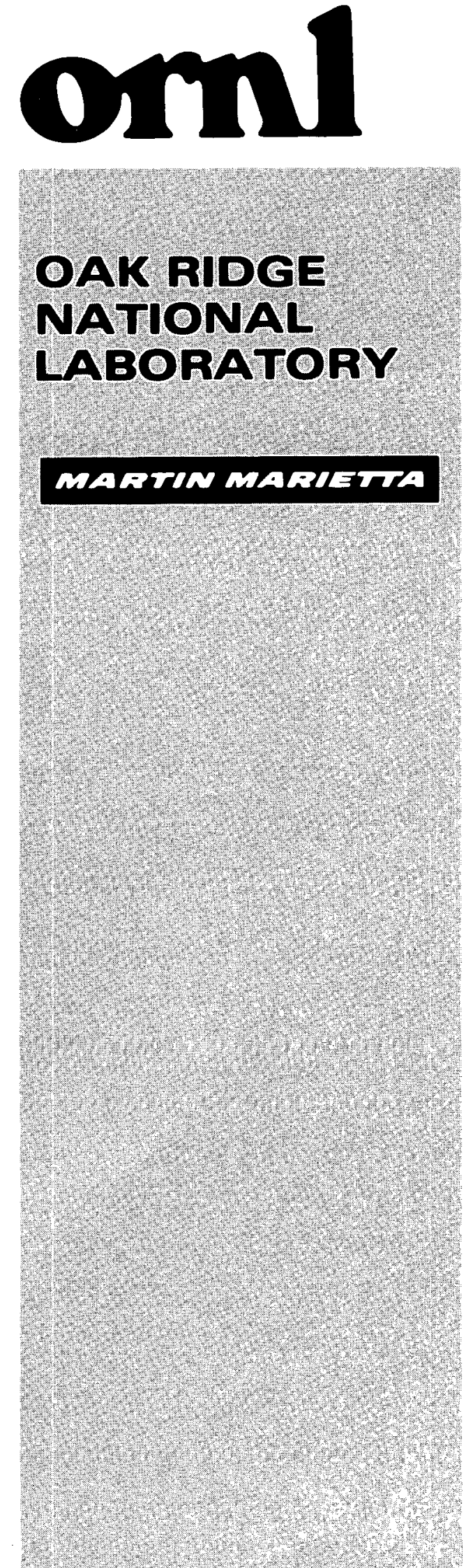

OPERATEO BY

MARTIN MARIETTA ENERGY SYSTEMS, INC

FOR THE UNITEO STATES

DEPARTMENT OF ENERGY
ORNL/RASA-88/102

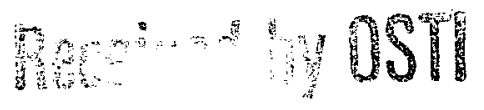

Afrit 101989

\section{PRELIMINARY SITE SURVEY REPORT FOR THE SACANDAGA SITE, GLENVILLE, NEW YORK}

\title{
MASTER
}

W. D. Cottrell

R. D. Foley

R. F. Carrier 


\section{Printed in the United States of America. Available from National Technical Information Service \\ U.S. Department of Commerce \\ 5285 Port Royal Road, Springfield, Virginia 22161 \\ NTIS price codes-Printed Copy: A03 Microfiche A01}

This report was prepared as an account of work sponsored by an agency of the United States Government. Neither the $U$ nited States Government nor any agency thereof, nor any of their employees, makes any warranty, express or implied, or assumes any legal liability or responsibility for the accuracy, completeness, or usefulness of any information, apparatus, product, or process disclosed, or represents that its use would not infringe privately owned rights. Reference herein to any specific commercial product, process, or service by trade name, trademark, manufacturer, or otherwise, does not necessarily constitute or imply its endorsement, recommendation, or favoring by the United States Government or any agency thereof. The views and opinions of authors expressed herein do not necessarily state or reflect those of the United States Government or any agency thereof. 


\section{DISCLAIMER}

This report was prepared as an account of work sponsored by an agency of the United States Government. Neither the United States Government nor any agency Thereof, nor any of their employees, makes any warranty, express or implied, or assumes any legal liability or responsibility for the accuracy, completeness, or usefulness of any information, apparatus, product, or process disclosed, or represents that its use would not infringe privately owned rights. Reference herein to any specific commercial product, process, or service by trade name, trademark, manufacturer, or otherwise does not necessarily constitute or imply its endorsement, recommendation, or favoring by the United States Government or any agency thereof. The views and opinions of authors expressed herein do not necessarily state or reflect those of the United States Government or any agency thereof. 


\section{DISCLAIMER}

Portions of this document may be illegible in electronic image products. Images are produced from the best available original document. 


\title{
HEALTH AND SAFETY RESEARCH DIVISION
}

Nuclear and Chemical Waste Programs (Activity No. AH 100500 0; ONLWCO1)

\section{PRELIMINARY SITE SURVEY REPORT FOR THE SACANDAGA SITE, GLENVILLE, NEW YORK}

\author{
W. D. Cottrell, R. D. Foley, and R. F. Carrier
}

Date of Issue - March 1989

\author{
Investigation Team
}

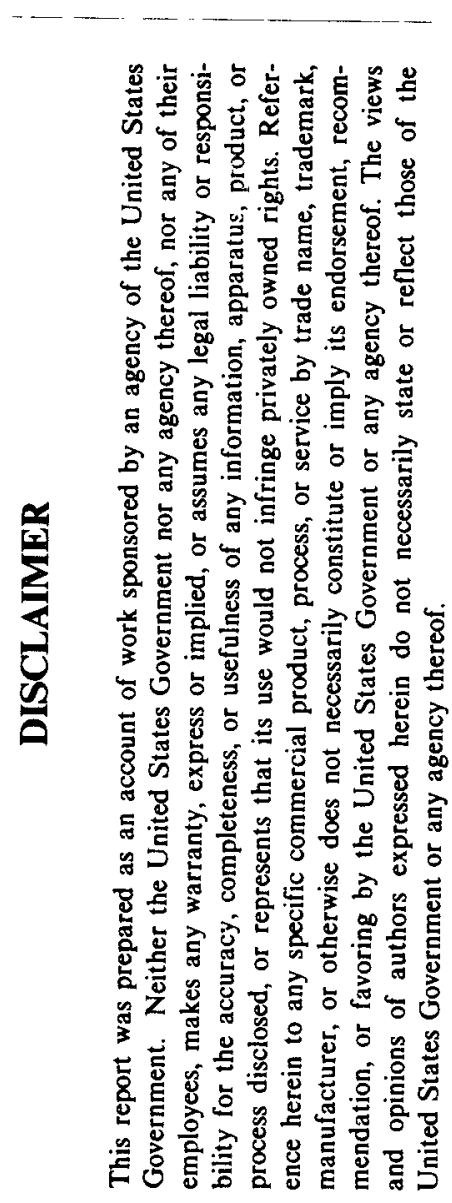

R. E. Swaja - Measurement Applications and Development Manager

W. D. Cottrell - FUSRAP Project Director

Dis docurnent is

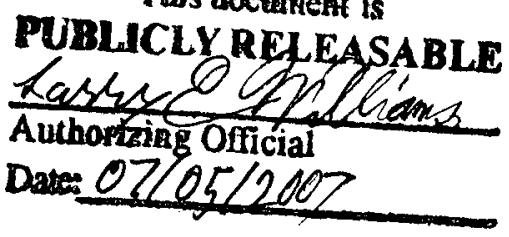

Work performed by the

MEASUREMENT APPLICATIONS AND DEVELOPMENT GROUP

Prepared by the

OAK RIDGE NATIONAL LABORATORY

Oak Ridge, Tennessee 37831-6285

operated by

MARTIN MARIETTA ENERGY SYSTEMS, INC.

for the

U. S. DEPARTMENT OF ENERGY

under Contract No. DE-AC05-84OR21400 


\section{CONTENTS}

LIST OF FIGURES . . . . . . . . . . . . . . . . . . . . . . . . . . v v LIST OF TABLES .......................... . . . vii

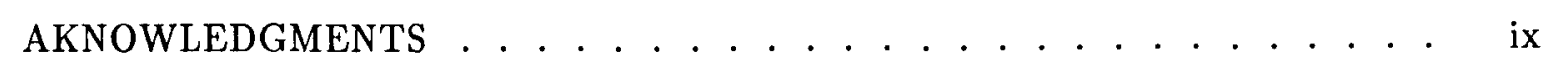
INTRODUCTION . . . . . . . . . . . . . . . . . . . . . . 1 SURVEY METHODS . . . . . . . . . . . . . . . . . . . . . 2

SURVEY RESULTS . . . . . . . . . . . . . . . . . . . . . . . . . 2

Indoor Survey Results . . . . . . . . . . . . . . . . . . . . . 2

Gamma Radiation Levels . . . . . . . . . . . . . . . . . . . . . . 2 Indoor Alpha and Beta-gamma Measurements . . . . . . . . . . . . . . 3

Outdoor Survey Results . . . . . . . . . . . . . . . . . . . 3

Gamma Radiation Levels . . . . . . . . . . . . . . . . . . . . . . 3

Systematic and Biased Soil Samples . . . . . . . . . . . . . . . . . 3 CONCLUSIONS . . . . . . . . . . . . . . . . . . . . . . . . . . . 4 REFERENCES . . . . . . . . . . . . . . . . . . . . . . . . 5 APPENDIX ............................. . . . . . 17 


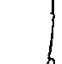

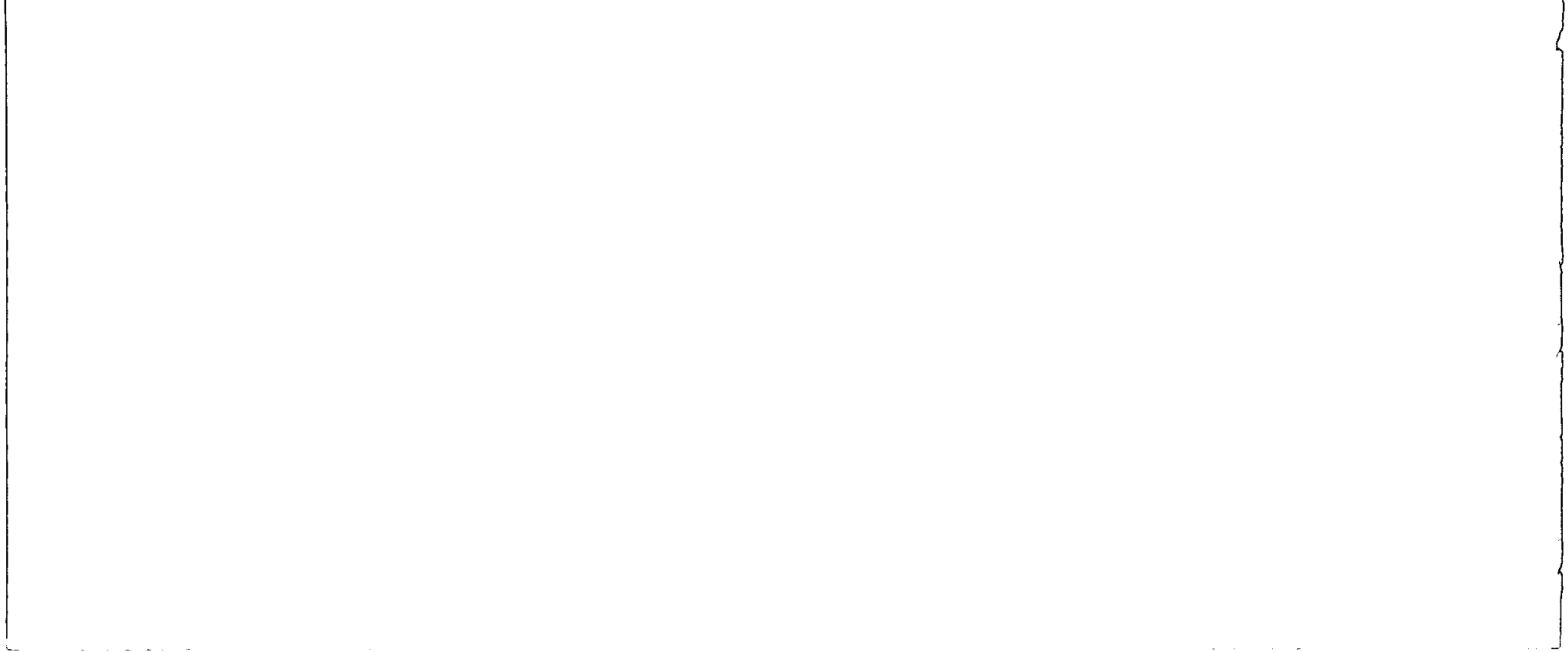




\section{LIST OF FIGURES}

1 Diagram showing general location of the Sacandaga Site . . . . . . . . . . 6

2 Diagram showing property boundaries and all buildings and structures as located during 1947-1951 operations at the Sacandaga Site . . . . . . . . . . . 7

3 View of the front of building $\mathrm{P}$ at the Sacandaga Site, looking north . . . . . . . . . . . . . . . . . . . . . . . . 8

4 View of the rear of building $\mathrm{P}$ at the Sacandaga Site, looking south . . . . . . . . . . . . . . . . . . . . . 9

5 View of typical outdoor area at the Sacandaga Site . . . . . . . . . . . . . 10

6 Diagram of Building $\mathrm{P}$ at the Sacandaga Site showing indoor gamma exposure rates and location of soil sample $\mathrm{S} 1$. . . . . . . . . . . . . . 11

7 Blowup of Sacandaga Site showing surveyed area and outdoor gamma exposure rates . . . . . . . . . . . . . . . . . . . . . . . 12

8 Blowup of Sacandaga Site showing surveyed area and locations of systematic (S) and biased (B) soil samples . . . . . . . . . . . . . . . . . 


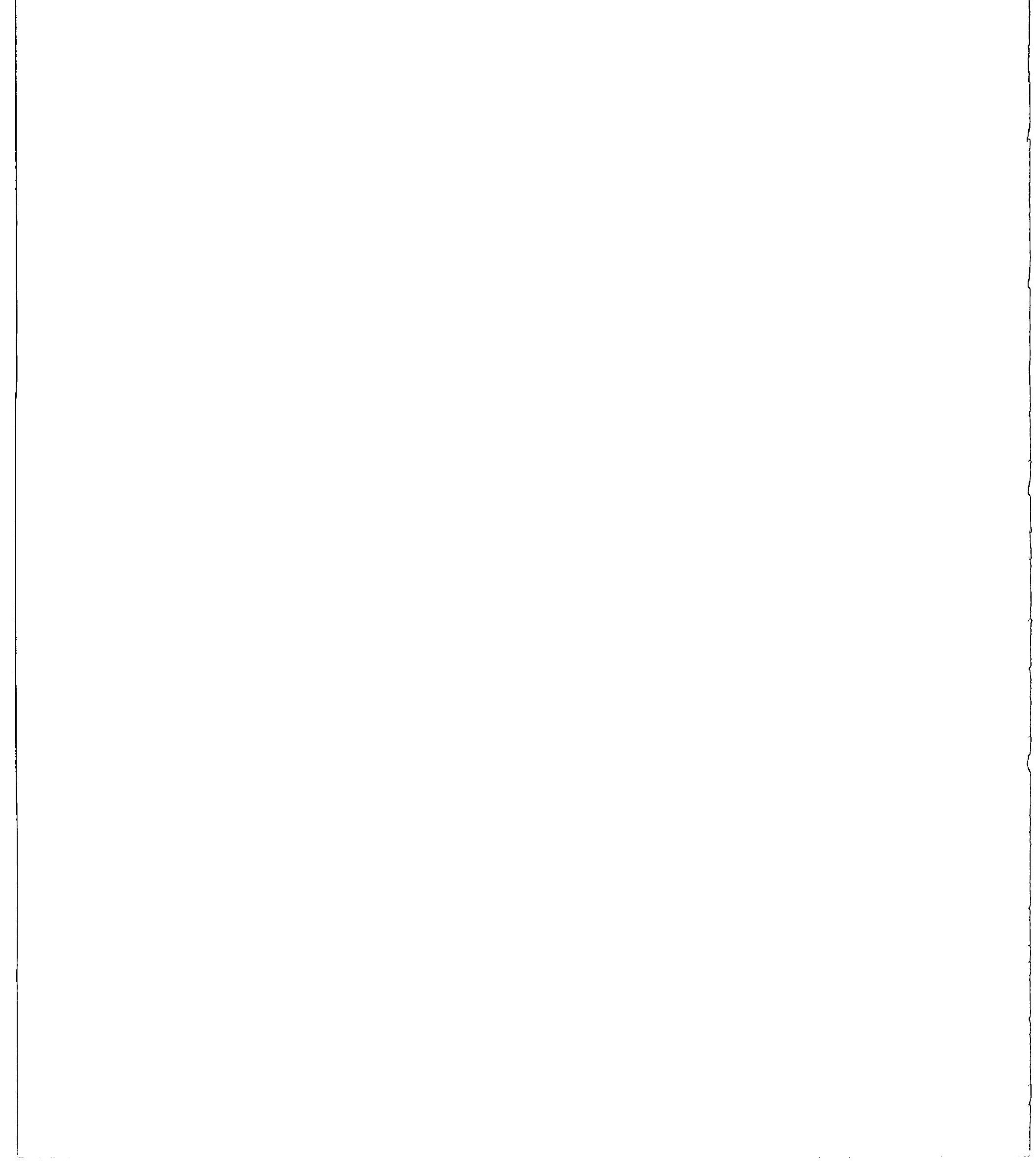




\section{LIST OF TABLES}

1 Background radiation levels in the Albany area . . . . . . . . . . . . . . . . 14

2 Applicable guidelines for protection against radiation . . . . . . . . . . . . . 15

3 Concentrations of radionuclides and beryllium in surface soil samples from the Sacandaga Site . . . . . . . . . . . . . . . . . 16 


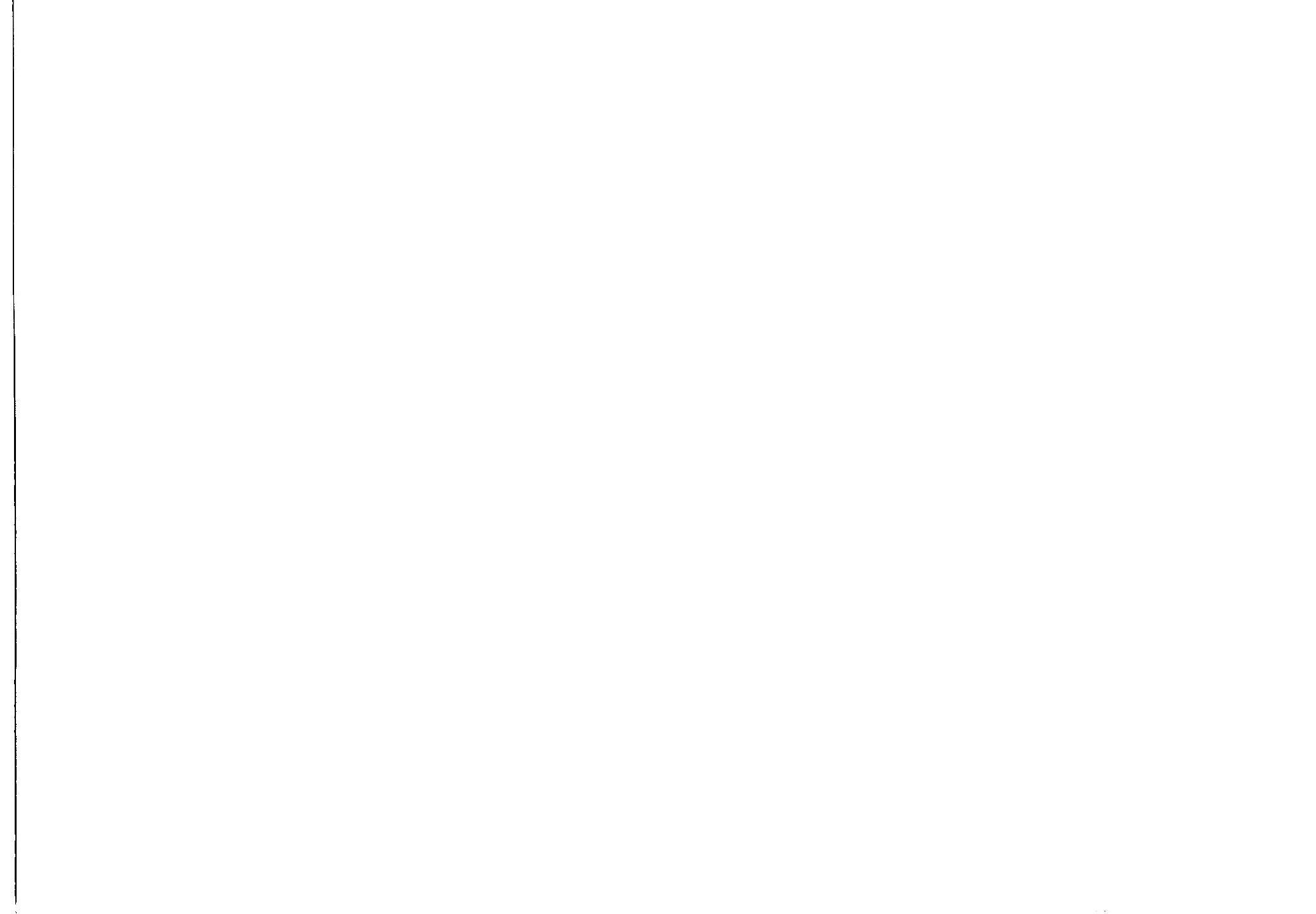

(1) 


\section{ACKNOWLEDGMENTS}

Research for this project was sponsored by the Division of Facility and Site Decommissioning Projects, U.S. Department of Energy, under Contract No. DE-AC05-840R21400 with Martin Marietta Energy Systems, Inc. The authors wish to acknowledge the support of J. E. Baublitz, Deputy Director, Office of Remedial Action and Waste Technology; J. J. Fiore, Director, Division of Facility and Site Decommissioning Projects; and members of their staff. The authors also appreciate the contributions of E. G. Balliff of the Research Reactors Division, and A. C. Butler, D. A. Roberts, and T. R. Stewart of the Measurement Applications and Development group for participating in the collection, reporting, and analysis of data, and the preparation of graphics for this report. 


\section{PRELIMINARY SITE SURVEY REPORT FOR THE SACANDAGA SITE, GLENVILLE, NEW YORK*}

\section{INTRODUCTION}

The Sacandaga Atomic Power Laboratory (SAPL), located on Sacandaga Road in the Town of Glenville, Schenectady County, New York, was operated by the General Electric Company Knolls Atomic Power Laboratory (KAPL) for the Atomic Energy commission (AEC) from 1947-1951 (Fig. 1). Originally used for the study and development of radar during World War II, the facilities housed later operations involving Physics studies and sodium technology development in support of breeder reactor design and other AEC programs. Of the numerous original buildings shown on Fig. 2, only Building P, the Critical Assembly Building, remains standing. Front and rear views of the small, concrete block building are shown in Figs. 3 and 4. The remaining structure is situated on $\sim 51$ acres of land most of which is covered by a heavy growth of trees and brush. An abundance of rubbish and dismantled structural materials is strewn throughout the site (Fig. 5). The present owner uses the building as a storage area. It is estimated that the total inventory of radioactive materials on the site included $\sim 300 \mathrm{~kg}$ of uranium in the form of solid metal discs, $\sim 8 \mathrm{mg}$ of plutonium on platinum discs covered with plastic, and $\sim 3 \mathrm{mg}$ of radium sealed in a radium/beryllium source. Both ${ }^{238} \mathrm{U}$ and ${ }^{235} \mathrm{U}$ in solid metal form were used in experiments for breeder reactor studies. With the termination of Thermal Test Reactor and Preliminary Pile Assembly operations in March, 1951, the Sacandaga equipment was dismantled and moved to the Knolls site in nearby Schenectady. ${ }^{1}$

The Office of Naval Reactors requested, through the office of Remedial Action and Waste Technology, that the radiological survey group from the Formerly Utilized Sites Remedial Action Program (FUSRAP) conduct an independent assessment of the radiological condition of the Sacandaga Site. This type of assessment typically involves a two-stage process. The first part consists of a site visit and preliminary scoping survey to verify that no radiological hazard exists at a specific site, and to collect sufficient data to plan the second part of the process - the more comprehensive radiological survey. The preliminary radiological scoping survey discussed in this report was conducted, at the request of DOE, by Oak Ridge National Laboratory on July 22, 1988. Compared to the large size of the property, the survey was limited in scope, including only the 5-6 acres enclosed within the fence and concentrating on those areas having the greatest possibility of containing residual

*The survey was performed by members of the Measurement Applications and Development Group of the Health and Safety Research Division at Oak Ridge National Laboratory under DOE contract DE-AC05-84OR21400. 
radioactive material. The survey team identified these areas through review of historical information provided by Naval Reactors and KAPL. ${ }^{1}$

\section{SURVEY METHODS}

Because the site is very large, the scoping survey was limited to a gamma scan at the surface in areas selected from review of the site history and discussions with KAPL personnel; collection of soil samples; and measurements of transferable alpha and beta-gamma activity levels inside the building. A comprehensive description of the survey methods and instrumentation has been presented in another report. ${ }^{2}$

Using a portable gamma scintillation meter, ranges of measurements were recorded by scanning the ground surface outdoors and within Building P. Systematic soil samples were then collected irrespective of gamma exposure rates. These sampling locations are selected as part of a sampling grid or to obtain a general representation of the radioactive content of the soil around the site without regard to gamma radiation levels. In addition, soil samples were collected from the ground surface $(0-20 \mathrm{~cm})$ in outdoor areas of elevated gamma levels. Samples taken in these locations are referred to as biased samples and are more likely to contain elevated radioactivity than systematic samples. All samples were analyzed for radionuclide content. Beryllium concentrations were determined in selected samples. Smears were also obtained from designated surfaces inside the building to establish transferable alpha and beta-gamma activity levels.

\section{SURVEY RESULTS}

Typical background radiation levels for the eastern New York area are listed in Table 1. These data are provided for comparison with survey results presented in this section. DOE guidelines for the release of property for unrestricted use are listed in Table 2. All direct measurement results presented in this report are gross readings; background radiation levels have not been subtracted. Similarly, background concentrations have not been subtracted from radionuclide concentrations measured in environmental samples.

\section{Indoor Survey Results}

\section{Gamma Radiation Levels}

Gamma exposure rates on surfaces inside Building $\mathrm{P}$ ranged from 5 to $6 \mu \mathrm{R} / \mathrm{h}$ (Fig. 6 ). The observed levels are lower than the typical average background gamma exposure rate of $9 \mu \mathrm{R} / \mathrm{h}$ found in the Schenectady/Albany area (Table 1). Background will vary from 
building to building depending upon particular construction materials and the type of soil on which the building rests. All values are below the DOE reference guideline of $20 \mu \mathrm{R} / \mathrm{h}$ above background for indoor areas (Table 2).

\section{Indoor Alpha and Beta-gamma Measurements}

Smear samples were obtained from various locations inside the building. Analysis of the smears showed that all measurements of transferable alpha activity levels were at background. Transferable beta-gamma measurements yielded levels ranging from background to $260 \mathrm{dpm} / 100 \mathrm{~cm}^{2}$. The maximum measurement, $260 \mathrm{dpm} / 100 \mathrm{~cm}^{2}$, was obtained in the open area of Building $\mathrm{P}$ (covered port, Fig. 6) and is well below the reference guideline of $1000 \mathrm{dpm} / 100 \mathrm{~cm}^{2}$ for removable beta-gamma surface contamination (Table 2).

\section{Outdoor Survey Results \\ Gamma Radiation Levels}

A scan of the surface outdoors on the property disclosed exposure rates generally ranging from 5 to $10 \mu \mathrm{R} / \mathrm{h}$ (Fig. 7). These values are within the range of typical background gamma levels (Table 1 ).

\section{Systematic and Biased Soil Samples}

Two systematic soil samples (S) were collected at two locations as shown on Fig. 8. The results of laboratory analyses are provided in Table 3 . Uranium-238 was found at concentrations of 1.3 and $1.9 \mathrm{pCi} / \mathrm{g}$ in these samples, slightly above typical background (Table 1). Concentrations of ${ }^{226} \mathrm{Ra}$ and ${ }^{232} \mathrm{Th}$ in systematic samples were 1.5 and $0.98 \mathrm{pCi} / \mathrm{g}$, and 2.5 and $1.1 \mathrm{pCi} / \mathrm{g}$, respectively, values also slightly in excess of background values. Cesium137 concentrations in two systematic surface soil samples were 0.34 and $0.76 \mathrm{pCi} / \mathrm{g}$, which are in the range of typical background concentrations due to fallout from nuclear weapons testing.

In seven biased (B) soil samples taken from six different locations of elevated gamma levels on the property, concentrations of ${ }^{238} \mathrm{U}$ ranged from $<1.5$ to $2.7 \mathrm{pCi} / \mathrm{g}$. These samples averaged $1.9 \mathrm{pCi} / \mathrm{g}$. The maximum uranium concentration was found in sample B10 (Fig. 8). Concentrations of ${ }^{226} \mathrm{Ra}$ and ${ }^{232} \mathrm{Th}$ in biased samples were 1.1 to $2.3 \mathrm{pCi} / \mathrm{g}$, averaging $1.5 \mathrm{pCi} / \mathrm{g}$, and 1.1 to $2.6 \mathrm{pCi} / \mathrm{g}$, averaging $1.6 \mathrm{pCi} / \mathrm{g}$, respectively. Cesium-137 concentrations ranged from $<0.02$ to $0.69 \mathrm{pCi} / \mathrm{g}$, averaging $0.23 \mathrm{pCi} / \mathrm{g}$. These values are typical of concentrations found in soil from fallout from nuclear weapons testing. 
The results of soil sample analyses show that concentrations of ${ }^{238} \mathrm{U},{ }^{226} \mathrm{Ra}$, and ${ }^{232} \mathrm{Th}$ are slightly higher than levels typical for the general Albany area (Table 1); however, they are no higher than levels measured in other areas having similar types of soil (i.e., soils containing shale and cinders). Concentrations of ${ }^{232} \mathrm{Th},{ }^{226} \mathrm{Ra}$ and ${ }^{238} \mathrm{U}$ at levels of 2-4 pCi/g are not inconsistent with concentrations of these radionuclides found in cinders from coal burning at other locations and, based on radionuclide ratios and concentrations, it appears that the primary source of most of the radioactivity in the samples is probably due to radionuclides naturally present in soil and ashes.

Representatives from the New York State Department of Environmental Conservation (NYSDEC) and the New York State Department of Health (NYSDOH) collected soil samples at this site coincident with the ORNL survey. However, in neither case were the samples actually split for independent analysis. NYSDEC/NYSDOH results are summarized in the appendix and were similar to ORNL results.

\section{CONCLUSIONS}

The results of the limited scoping survey of a portion of the Sacandaga Site reveal no data to indicate that residual radioactivity from former operations exists either indoors or outdoors on that portion of the site surveyed. However, since this property contains approximately 51 acres and the limited survey covered only that portion of the site that contained the process and associated service buildings (5-6 acres), the data from this survey, while indicative, is not a comprehen sive assessment of the radiological condition of the entire site. If a higher degree of confidence is desired, a more detailed survey of at least a portion of the site would be required. This detailed survey should include subsurface investigation of those areas known to contain buried rubble from demolished structures formerly part of the site. Soil samples should also be collected and analyzed for ${ }^{226} \mathrm{Ra},{ }^{232} \mathrm{Th},{ }^{238} \mathrm{U},{ }^{137} \mathrm{Cs}$, ${ }^{239} \mathrm{Pu}$, and non-radioactive beryllium. 


\section{REFERENCES}

1. B. F. Knapp, General Electric Company, to The Manager, Schenectady Naval Reactors Office, U. S. DOE, "History and Radiological Status of the KAPL Peek Street Site and The KAPL Sacandaga Site" RHEP-30-1685 (August 24, 1979).

2. T. E. Myrick, B. A. Berven, W. D. Cottrell, W. A. Goldsmith, and F. F. Haywood, Procedures Manual for the ORNL Radiological Survey Activities (RASA) Program, Oak Ridge National Laboratory, ORNL/TM-8600 (April 1987).

3. T. E. Myrick and B. A. Berven, State Background Radiation Levels: Results of Measurements Taken During 1975-1979, Oak Ridge National Laboratory, ORNL/TM7343 (November 1981). 
ORNL-DWG 89-7331

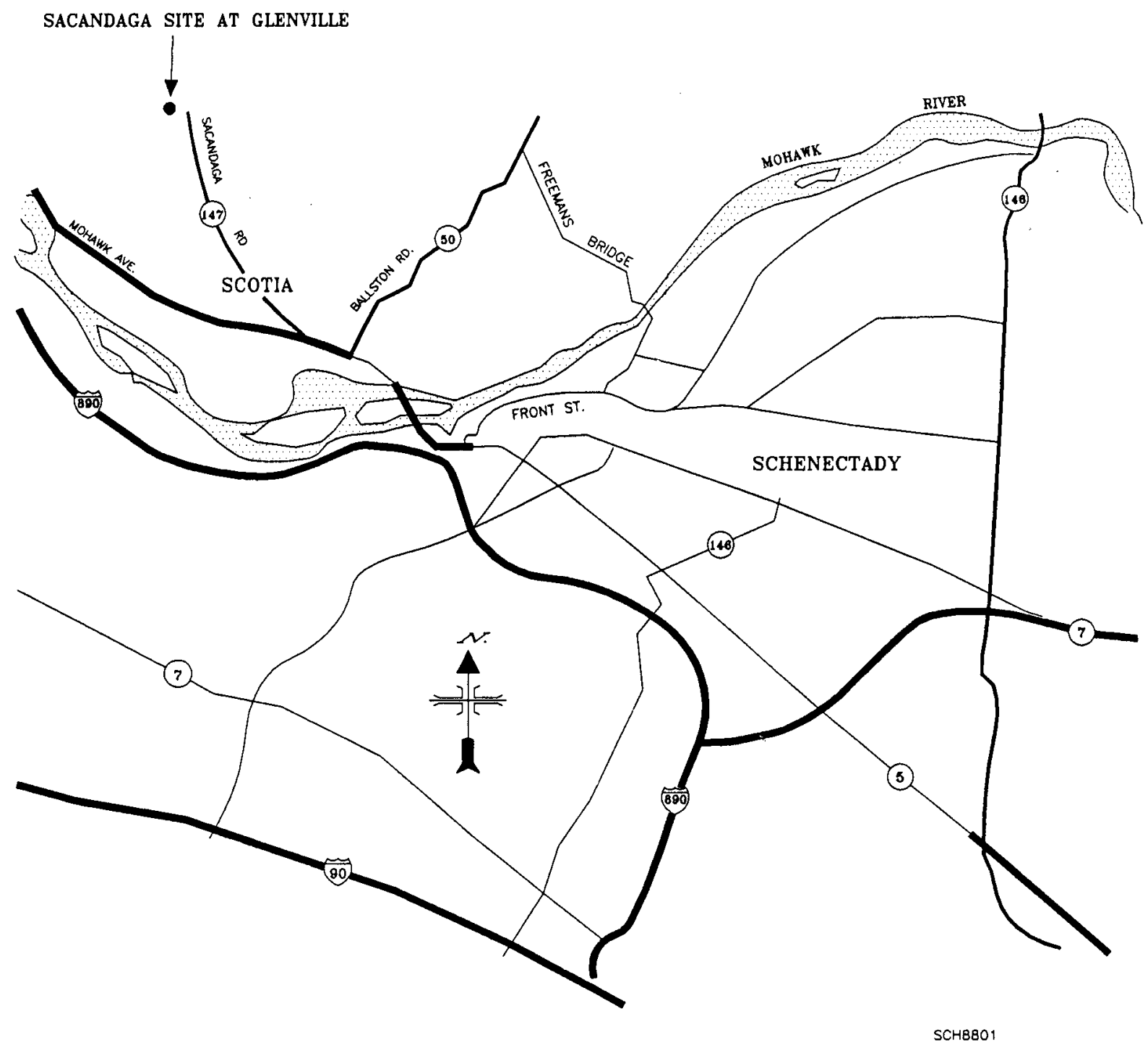

Fig. 1. Diagram showing general location of the Sacandaga Site. 


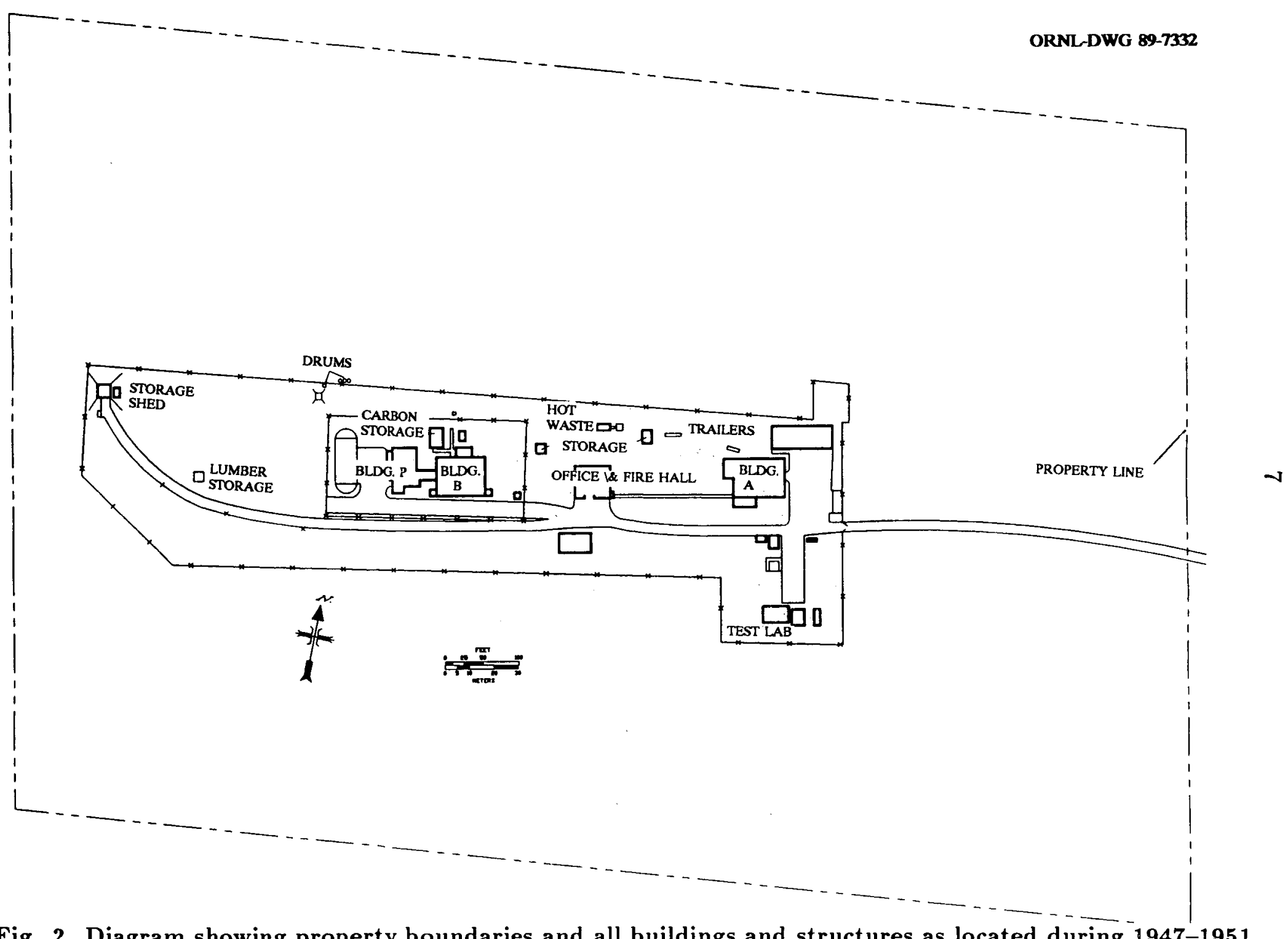

Fig. 2. Diagram showing property boundaries and all buildings and structures as located during 1947-1951 operations at the Sacandaga Site. (Blowup, Fig. 7, p. 12.) 


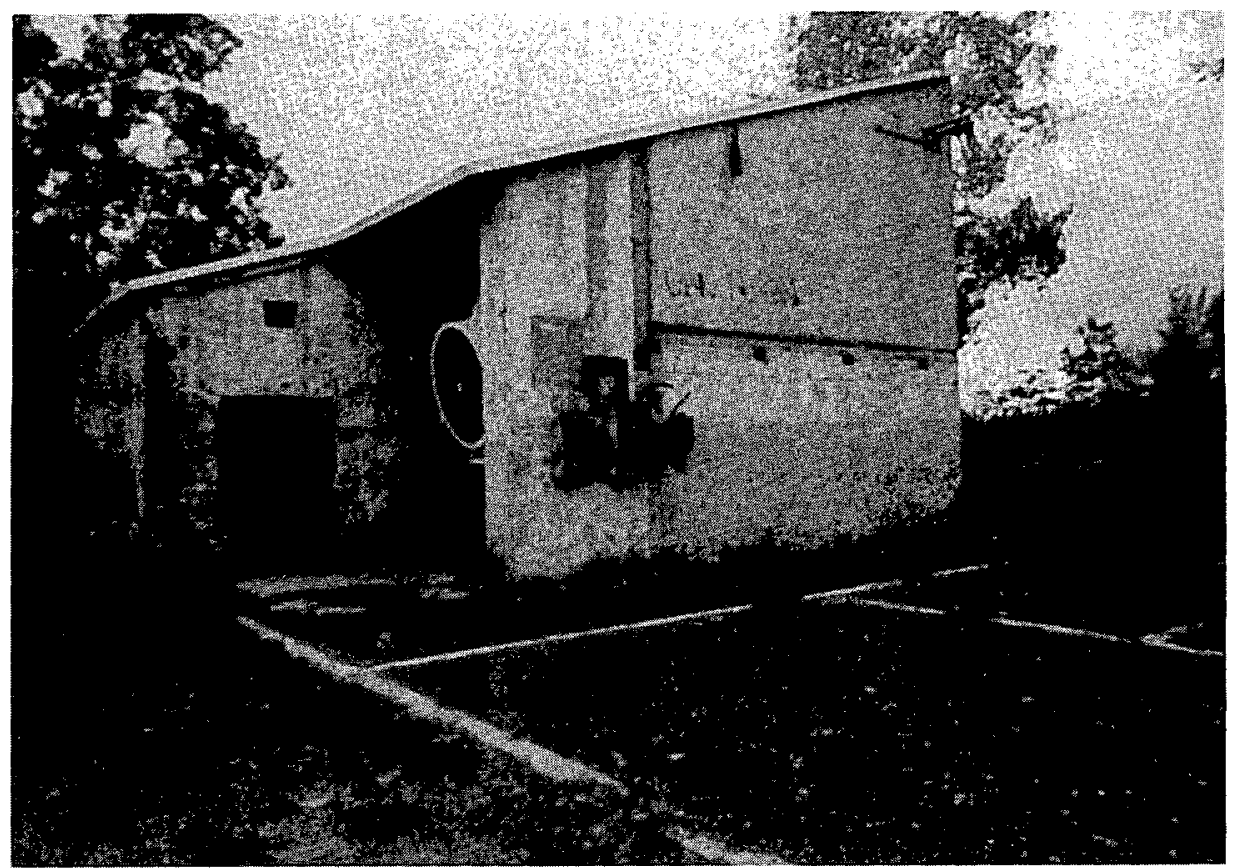

Fig. 3. View of the front of Building $P$ at the Sacandaga Site, looking north. 


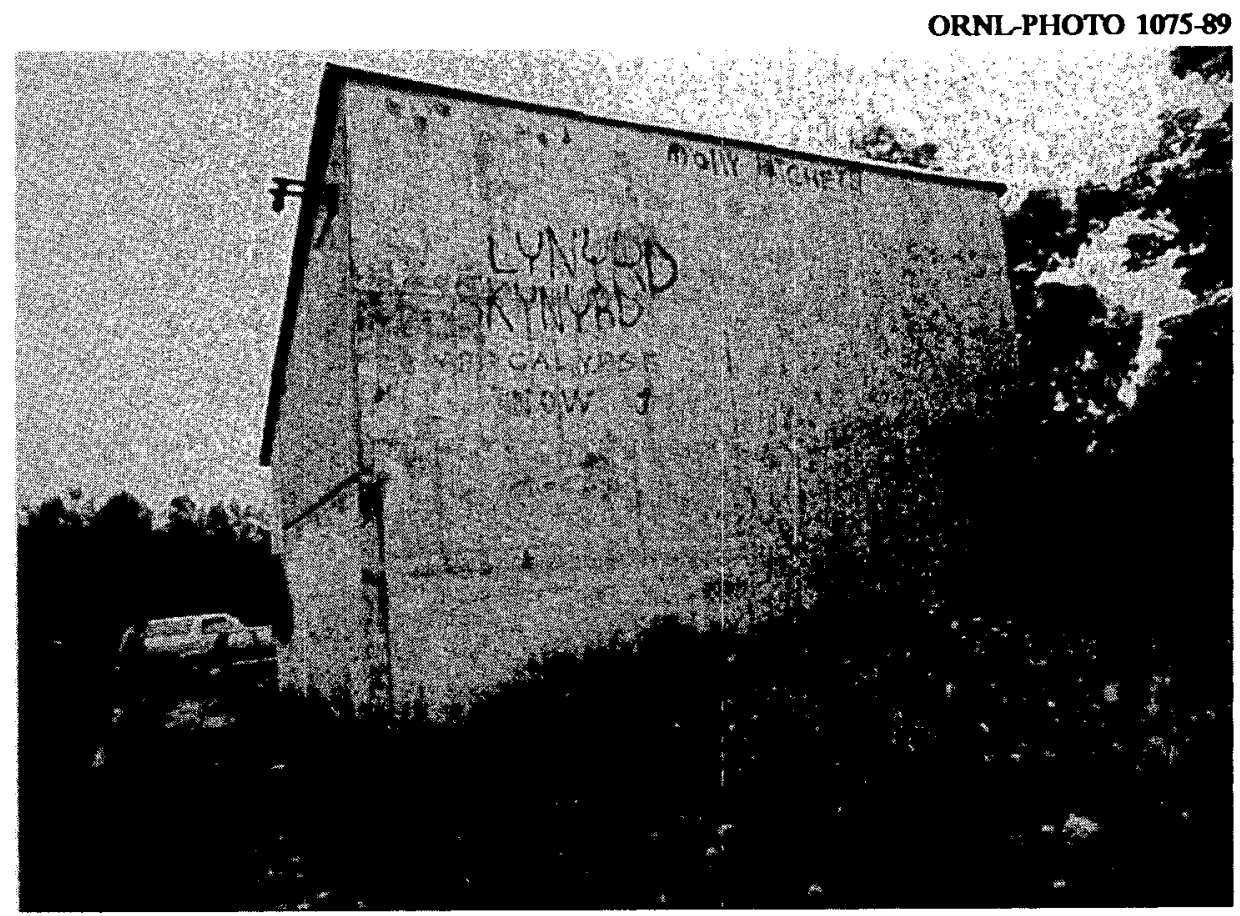

Fig. 4. View of the rear of Building $P$ at the Sacandaga Site, looking south. 


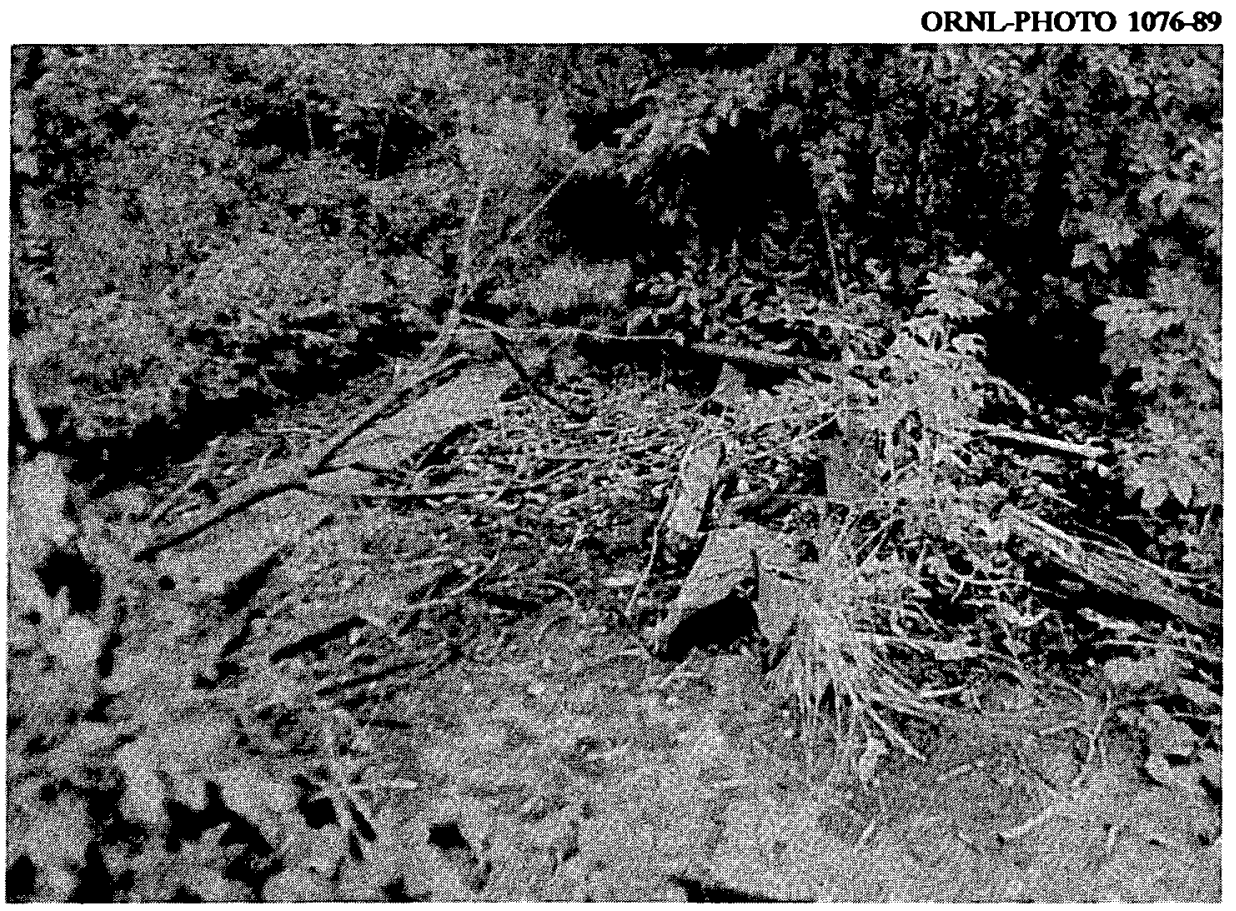

Fig. 5. View of typical outdoor area at the Sacandaga Site. 


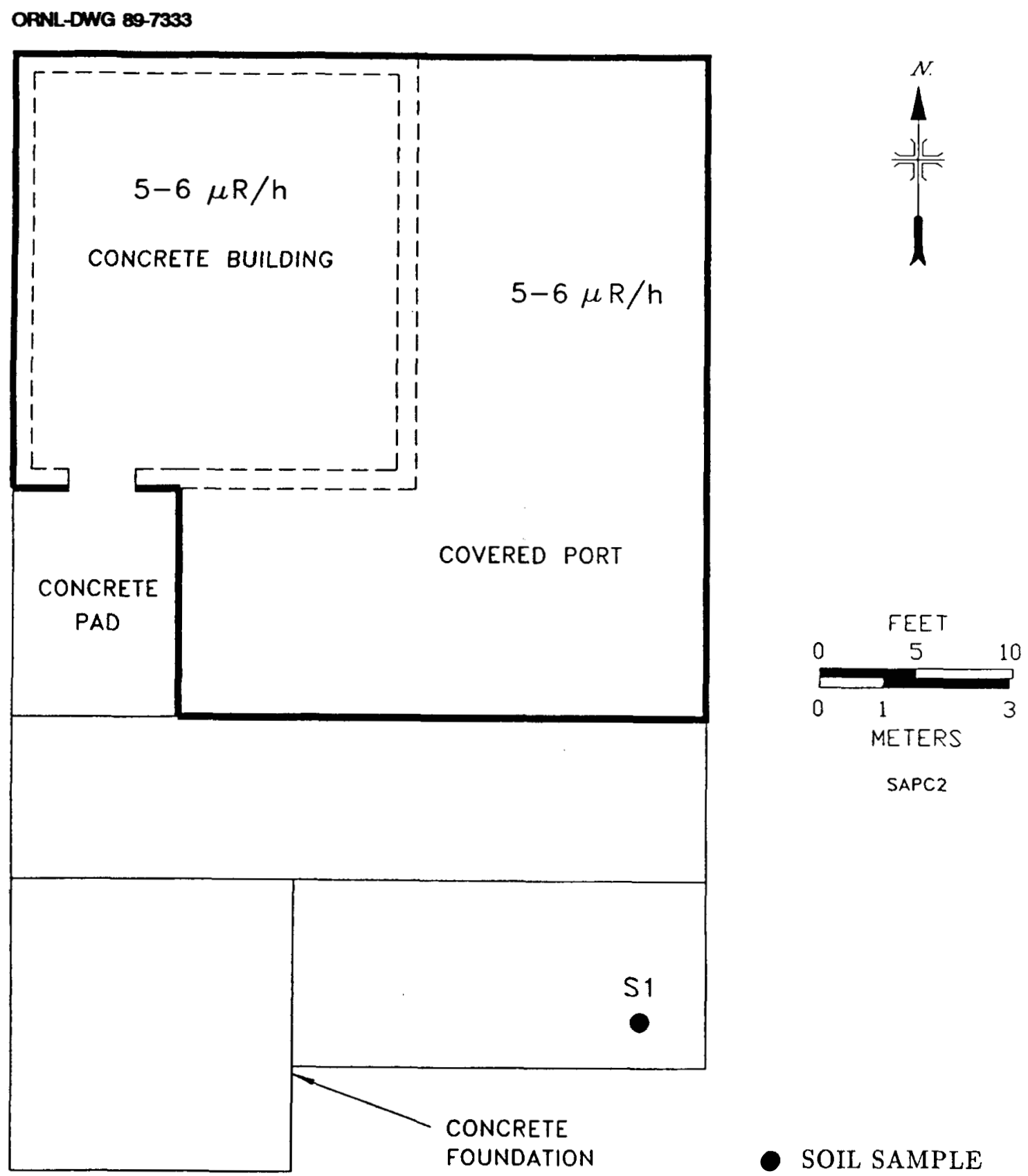

Fig. 6. Diagram of Building $P$ at the Sacandaga site showing indoor gamma exposure rates and location of soil sample $S 1$. 


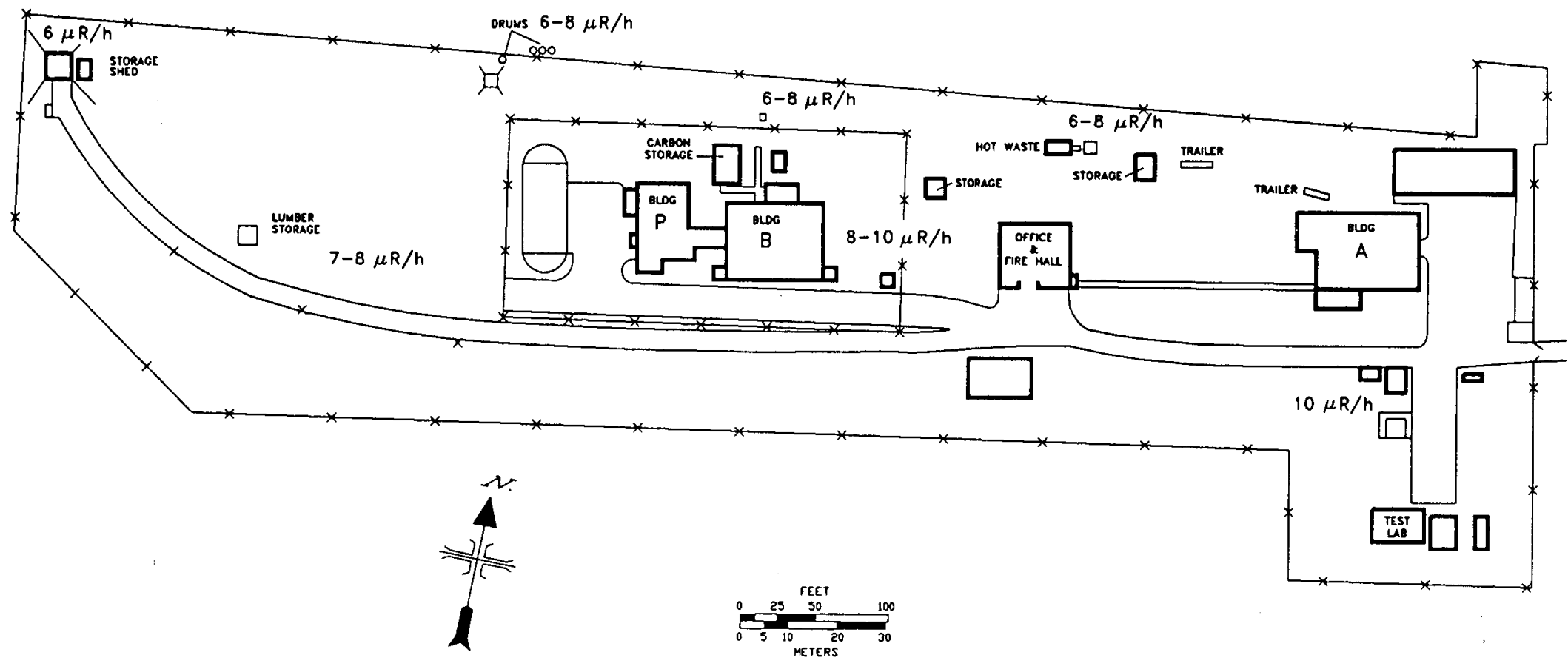

Fig. 7. Blowup of Sacandaga Site showing surveyed area and outdoor gamma exposure rates. 


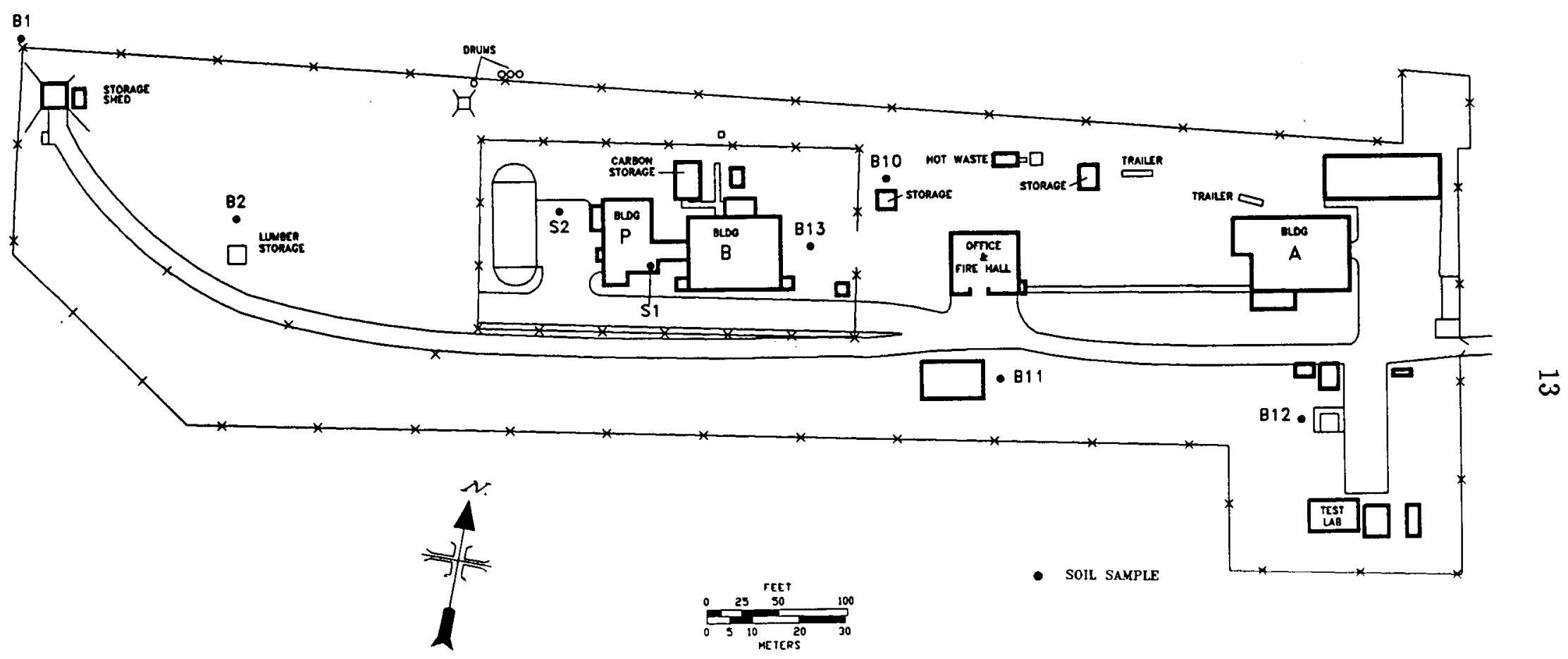

Fig. 8. Blowup of Sacandaga Site showing surveyed area and locations of systematic (S) and biased (B) soil samples. 
Table 1. Background radiation levels in the Albany area

\begin{tabular}{llc}
\hline $\begin{array}{c}\text { Type of radiation } \\
\text { measurement or sample }\end{array}$ & \multicolumn{2}{c}{$\begin{array}{c}\text { Radiation level or } \\
\text { radionuclide concentration }\end{array}$} \\
\cline { 2 - 3 } & Range & Average \\
\hline Gamma exposure rate at $1 \mathrm{~m}$ above & $8-10$ & 9 \\
floor or ground surface $(\mu \mathrm{R} / \mathrm{h})^{\mathrm{a}}$ & & \\
& & \\
Concentration of radionuclides & & 0.96 \\
in soil $(\mathrm{pCi} / \mathrm{g})^{\mathrm{b}}$ & & 0.85 \\
${ }^{238} \mathrm{U}$ & $0.76-1.2$ & \\
${ }^{226} \mathrm{Ra}$ & $0.48-1.2$ & \\
\hline
\end{tabular}

${ }^{a}$ Values obtained from four locations in the Albany area.

bSoil samples (NY1-NY6) obtained from six locations around the Albany area. ${ }^{3}$ 
Table 2. Applicable guidelines for protection against radiation ${ }^{\mathrm{a}}$

(Limits for uncontrolled areas)

\begin{tabular}{|c|c|c|}
\hline Mode of exposure & Exposure conditions & Guideline value \\
\hline Gamma radiation & $\begin{array}{l}\text { Indoor gamma radiation level } \\
\text { (above background) }\end{array}$ & $20 \mu \mathrm{R} / \mathrm{h}$ \\
\hline \multirow[t]{4}{*}{$\begin{array}{l}\text { Surface contam- } \\
\text { ination }^{b}\end{array}$} & $\begin{array}{l}{ }^{238} \mathrm{U}, \mathrm{U} \text {-natural } \\
\text { Fixed on surfaces } \\
\text { Removable }\end{array}$ & $\begin{array}{l}5000 \mathrm{dpm} / 100 \mathrm{~cm}^{2} \\
1000 \mathrm{dpm} / 100 \mathrm{~cm}^{2}\end{array}$ \\
\hline & $\begin{array}{l}\text { Beta-gamma emitters } \\
\text { Fixed on surfaces } \\
\text { Removable }\end{array}$ & $\begin{array}{l}5000 \mathrm{dpm} / 100 \mathrm{~cm}^{2} \\
1000 \mathrm{dpm} / 100 \mathrm{~cm}^{2}\end{array}$ \\
\hline & $\begin{array}{l}{ }^{232} \mathrm{Th} \text {, Th-natural } \\
\text { Fixed on surfaces } \\
\text { Removable }\end{array}$ & $\begin{array}{r}1000 \mathrm{dpm} / 100 \mathrm{~cm}^{2} \\
200 \mathrm{dpm} / 100 \mathrm{~cm}^{2}\end{array}$ \\
\hline & $\begin{array}{l}{ }^{226} \mathrm{Ra} \text {, transuranics } \\
\text { Fixed on surfaces } \\
\text { Removable }\end{array}$ & $\begin{array}{r}100 \mathrm{dpm} / 100 \mathrm{~cm}^{2} \\
20 \mathrm{dpm} / 100 \mathrm{~cm}^{2}\end{array}$ \\
\hline \multirow[t]{2}{*}{$\begin{array}{l}\text { Beta-gamma dose } \\
\text { rates }\end{array}$} & $\begin{array}{l}\text { Surface dose rate averaged } \\
\text { over not more than } 1 \mathrm{~m}^{2}\end{array}$ & $0.20 \mathrm{mrad} / \mathrm{h}$ \\
\hline & $\begin{array}{l}\text { Maximum dose rate in any } \\
100 \mathrm{~cm}^{2} \text { area }\end{array}$ & $1.0 \mathrm{mrad} / \mathrm{h}$ \\
\hline \multirow[t]{2}{*}{$\begin{array}{l}\text { Radionuclide } \\
\text { concentrations } \\
\text { in soil }\end{array}$} & $\begin{array}{l}\text { Maximum permissible concentration } \\
\text { of the following radionuclides in } \\
\text { soil above background levels } \\
\text { averaged over } 100 \mathrm{~m}^{2} \text { area } \\
{ }^{232} \mathrm{Th} \\
{ }^{230} \mathrm{Th} \\
{ }^{228} \mathrm{Ra} \\
{ }^{226} \mathrm{Ra}\end{array}$ & $\begin{array}{l}5 \mathrm{pCi} / \mathrm{g} \text { averaged over } \\
\text { the first } 15 \mathrm{~cm} \text { of soil } \\
\text { below the surface; } \\
15 \mathrm{pCi} / \mathrm{g} \text { when averaged } \\
\text { over } 15-\mathrm{cm} \text { thick soil } \\
\text { layers more than } 15 \mathrm{~cm} \\
\text { below the surface }\end{array}$ \\
\hline & ${ }^{238} \mathrm{U}$ & Derived (site specific) \\
\hline
\end{tabular}

${ }^{a}$ U.S. Department of Energy Guidelines for Residual Radioactivity at Formerly Utilized Sites Remedial Action Program and Remote Surplus Facilities Management Program Sites (Revision 2, March 1987).

${ }^{b}$ DOE surface contamination guidelines are consistent with NRC Guidelines for Decontamination at Facilities and Equipment Prior to Release for Unrestricted use or Termination of Licenses for By-Product, Source, or Special Nuclear Material (May 1987).

'Beta-gamma emitters (radionuclides with decay modes other than alpha emission or spontaneous fission) except ${ }^{90} \mathrm{Sr},{ }^{228} \mathrm{Ra},{ }^{223} \mathrm{Ra},{ }^{227} \mathrm{Ac},{ }^{133} \mathrm{I},{ }^{131} \mathrm{I},{ }^{129} \mathrm{I},{ }^{126} \mathrm{I}$, and ${ }^{125} \mathrm{I}$. 
Table 3. Concentrations of radionuclides and beryllium in surface soil samples from the Sacandaga Site

\begin{tabular}{|c|c|c|c|c|c|c|}
\hline \multirow{2}{*}{$\begin{array}{c}\text { Sample } \\
\text { number }^{\mathrm{a}}\end{array}$} & \multirow{2}{*}{$\begin{array}{l}\text { Depth } \\
\text { (cm) }\end{array}$} & \multicolumn{4}{|c|}{ Radionuclide concentration ( $\mathrm{pCi} / \mathrm{g}$ ) } & \multirow{2}{*}{$\begin{array}{c}\mathrm{Be} \\
(\mu \mathrm{g} / \mathrm{g})\end{array}$} \\
\hline & & ${ }^{226} \mathrm{Ra}^{\mathrm{b}}$ & ${ }^{232} \mathrm{Th}^{\mathrm{b}}$ & ${ }^{238} \mathrm{U}^{\mathrm{b}}$ & ${ }^{137} \mathrm{Cs}^{\mathrm{b}}$ & \\
\hline \multicolumn{7}{|c|}{ Systematic Samples $^{\mathrm{c}}$} \\
\hline $\mathbf{S} 1$ & $0-5$ & $1.5 \pm 0.01$ & $2.5 \pm 0.02$ & $1.3 \pm 0.04$ & $0.76 \pm 0.01$ & d \\
\hline $\mathrm{S} 2$ & $0-15$ & $0.98 \pm 0.008$ & $1.1 \pm 0.02$ & $1.9 \pm 0.3$ & $0.34 \pm 0.01$ & 1.1 \\
\hline \multicolumn{7}{|c|}{ Biased Samples ${ }^{\mathrm{e}}$} \\
\hline B1 & $0-8$ & $1.1 \pm 0.02$ & $1.1 \pm 0.03$ & $1.1 \pm 0.02$ & $0.69 \pm 0.01$ & 1.3 \\
\hline B2 & $0-15$ & $1.3 \pm 0.06$ & $1.4 \pm 0.2$ & $1.8 \pm 0.08$ & $0.059 \pm 0.02$ & d \\
\hline B10 & $0-15$ & $2.3 \pm 1$ & $2.6 \pm 0.4$ & $<1.5$ & $<0.04$ & $\mathrm{~d}$ \\
\hline B11A & $0-10$ & $2.2 \pm 0.06$ & $2.4 \pm 0.1$ & $2.7 \pm 2$ & $0.12 \pm 0.04$ & d \\
\hline B11B & $10-20$ & $1.2 \pm 0.03$ & $1.2 \pm 0.05$ & $<2.6$ & $<0.022$ & d \\
\hline B12 & $0-10$ & $1.2 \pm 0.06$ & $1.3 \pm 0.06$ & $1.7 \pm 0.2$ & $<0.02$ & $<1$ \\
\hline B13 & $0-8$ & $1.2 \pm 0.02$ & $1.2 \pm 0.03$ & $1.7 \pm 0.2$ & $0.065 \pm 0.01$ & $\mathrm{~d}$ \\
\hline
\end{tabular}

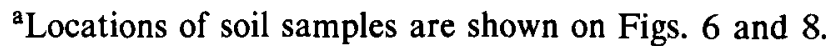

${ }^{b}$ Indicated counting error is at the $95 \%$ confidence level $( \pm 2 \sigma)$.

'Systematic samples are taken at selected locations irrespective of gamma exposure.

${ }^{\mathrm{d}}$ No analysis performed.

${ }^{e}$ Biased soil samples are taken from areas shown to have elevated gamma exposure rates. 


\title{
APPENDIX
}

\author{
Comparison of \\ NYSDEC/NYSDOH and ORNL \\ Soil Sample Results
}




\section{APPENDIX}

The New York State Department of Environmental Conservation (NYSDEC) and the New York State Department of Health (NYSDOH) collected soil samples independent from, but concurrent with the ORNL survey of the Sacandaga Site. The locations of NYSDEC/NYSDOH soil samples and the results of their analyses are shown in the following diagram and table. ORNL sample locations and results are indicated in Fig. 8 and Table 3 of this report.

A comparison of the separate radionuclide analyses of the soil samples shows a range of concentrations for ${ }^{238} \mathrm{U}$ of 0.8 to $2.4 \mathrm{pC} / \mathrm{g}$ (NYSDEC/NYSDOH) and 1.1 to $2.7 \mathrm{pCi} / \mathrm{g}$ (ORNL). Considering the analytical variables, including the stipulated counting errors and the fact that the state data refer to wet weight, the results are similar. Only ORNL sample $\mathrm{B} 13$ and NYSDEC/NYSDOH sample 885272 were taken from the same general location on the property. The content of ${ }^{238} \mathrm{U}$ in those two samples was 1.7 and $2.4 \mathrm{pCi} / \mathrm{g}$, respectively, and the corresponding ${ }^{226} \mathrm{Ra}$ concentrations were 1.2 and $1.0 \mathrm{pCi} / \mathrm{g}$. Although the results for some samples show concentrations of ${ }^{238} \mathrm{U}$ slightly elevated above average background levels for the general Albany area, they are in the range of background levels measured in other areas containing similar material (i. e., shale and cinders). 
ORNL-DWG 89-7336

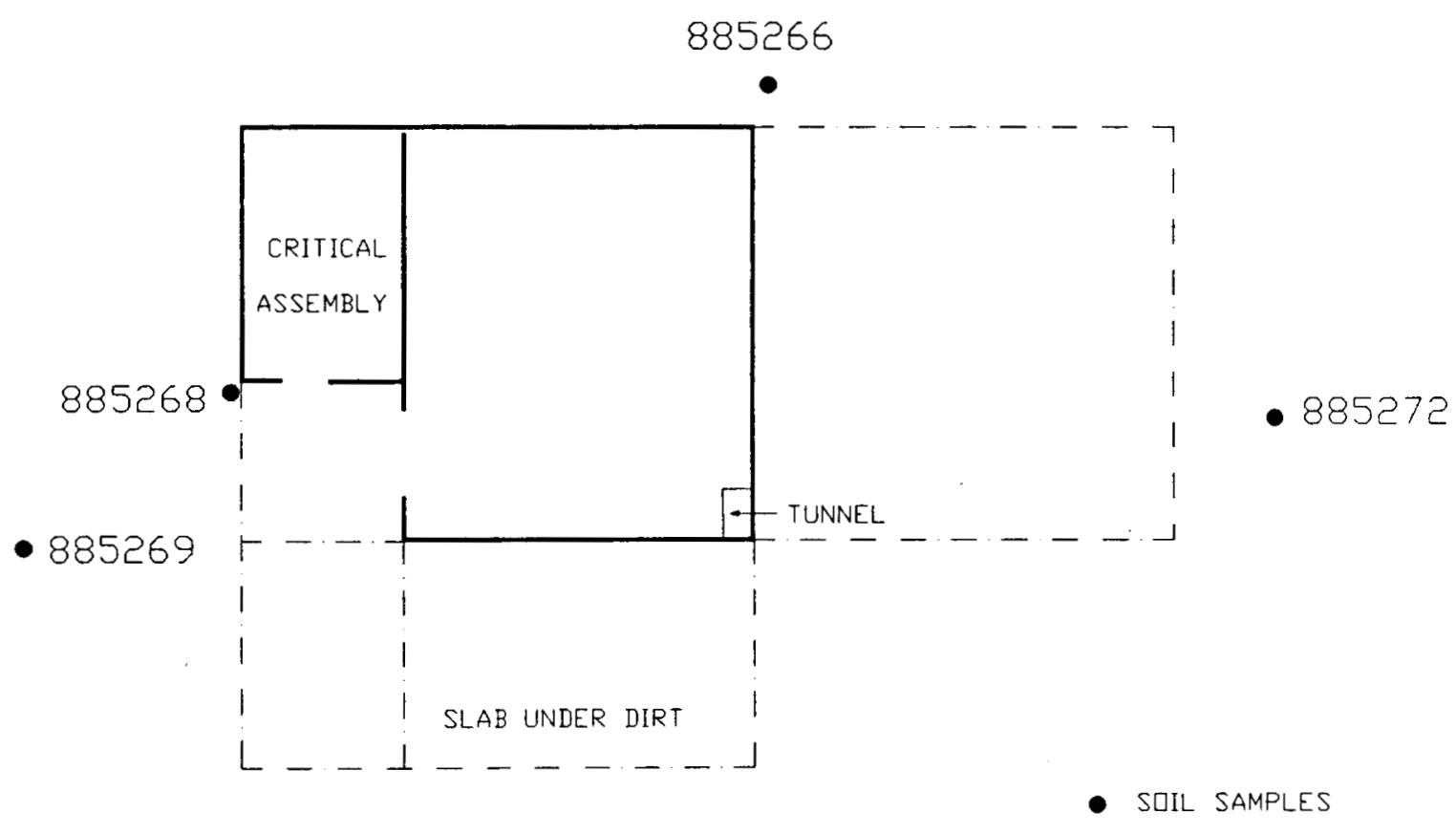

Fig. A.1 Building P (Critical Assembly Building) on the Sacandaga Site showing locations of NYSDEC/NYSDOH soil samples. 
Concentrations of principal radionuclides in soil samples from the former KAPL Sacandaga Street Site, Glenville, New York

Data provided by NYSDEC/NYSDOH ${ }^{a}$

\begin{tabular}{ccccc}
\hline \multirow{2}{*}{$\begin{array}{c}\text { NYSDEC } \\
\text { Sample } \\
\text { number }\end{array}$} & \multicolumn{4}{c}{ Radionuclide concentration $(\mathrm{pCi} / \mathrm{g})$} \\
\cline { 2 - 5 } & \multicolumn{1}{c}{${ }^{226} \mathrm{Ra}$} & ${ }^{232} \mathrm{Th}$ & ${ }^{238} \mathrm{U}$ & ${ }^{235} \mathrm{U}$ \\
\hline 885267 & $1.6 \pm 0.3$ & $1.7 \pm 0.2$ & $2.2 \pm 1.3$ & $<0.4$ \\
885268 & $0.49 \pm 0.08$ & $0.71 \pm 0.06$ & $1.3 \pm 0.4$ & $<0.12$ \\
885269 & $0.49 \pm 0.19$ & $0.61 \pm 0.1$ & 1.4 & $<0.3$ \\
885271 & $0.81 \pm 0.13$ & $0.77 \pm 0.11$ & $0.8 \pm 0.5$ & 0.2 \\
885272 & $1.0 \pm 0.2$ & $1.2 \pm 0.18$ & $2.4 \pm 1.2$ & $<0.3$ \\
\hline
\end{tabular}

${ }^{a}$ New York State Department of Environmental Conserva.* tion (NYSDEC); New York State Department of Health (NYSDOH).

${ }^{b}$ See attached map for sampling locations. 


\section{INTERNAL DISTRIBUTION}

\author{
1. B. A. Berven \\ 2-4. R. F. Carrier \\ 5-10. W. D. Cottrell \\ 11. A. G. Croff \\ 12. J. W. Crutcher \\ 13. J. T. Ensminger \\ 14. L. M. Floyd
}

\author{
15-20. R. D. Foley \\ 21. S. V. Kaye \\ 22. P. T. Owen \\ 23-25. R. E. Swaja \\ 26. J. K. Williams \\ 27. IR\&A Publications Office \\ 28. Laboratory Records - RC
}

\section{EXTERNAL DISTRIBUTION}

29. J. D. Berger, Oak Ridge Associated Universities, P. O. Box 117, Oak Ridge, TN 37831

30. R. W. Doane, Eberline, Inc., 800 Oak Ridge Turnpike, Oak Ridge, TN 37831

31. J. J. Fiore, U.S. Department of Energy, 19901 Germantown Road, Germantown, MD 20874

32-34. P. J. Gross, U.S. Department of Energy, P. O. Box E, Oak Ridge, TN 37831

35-37. G. K. Hovey, Bechtel National, Inc., 800 Oak Ridge Turnpike, Oak Ridge, TN 37831

38. L. R. Levis, Roy F. Weston, Inc., 20030 Century Blvd., Germantown, MD 20874

39-64. J. J. Mangeno, Department of Energy, NE-60, Naval Reactors, Crystal City, Arlington, VA 22202

65. G. P. Turi, U.S. Department of Energy, 19901 Germantown Road, Germantown, MD 20874

66. J. W. Wagoner, U.S. Department of Energy, 19901 Germantown Road, Germantown, MD 20874

67-69. Andrew Wallo III, U.S. Department of Energy, 19901 Germantown Road, Germantown, MD 20874

70. Office of Assistant Manager, Energy Research and Development, Oak Ridge Operations Office, Oak Ridge, TN 37831

71-72. Office of Scientific and Technical Information, DOE, Oak Ridge, TN 37831 